\title{
Customer's Perception about Banks Technology for Innovative Delivery Channels of Public Sector Banks (PSBs) of India
}

\author{
Vandana Tandon Khanna ${ }^{1} \&$ Neha Gupta ${ }^{1}$ \\ ${ }^{1}$ K. J. Somaiya Institute of Management Studies and Research, Mumbai, India \\ Correspondence: Neha Gupta, K. J. Somaiya Institute of Management Studies and Research, Vidyanagar, \\ Vidyavihar (east), Mumbai, 400077, India. Tel: 91-981-914-8730. E-mail: neha_prasad2005@yahoo.com
}

Received: October 13, 2014

Accepted: December 3, 2014

Online Published: January 20, 2015

doi:10.5539/ijbm.v10n2p214

URL: http://dx.doi.org/10.5539/ijbm.v10n2p214

\begin{abstract}
Purpose: The present study aims to focus on the customer's perception about technology being used for delivery of financial products and services by Public Sector Banks (PSBs) of India.

Design/methodology/approach: The study was based on primary data collected through structured questionnaire. The survey as well as in person interview of Bank's customers and Bank managers have been conducted to understand the factors influencing customers' perception about the technology used for innovative delivery channels by PSBs on five factors viz., acceptability, safety, availability, user friendliness and accessibility. The random sampling was used and the size of the sample was 304 . Hence, the type of study was exploratory and descriptive in nature.
\end{abstract}

Findings: The study finds that public sector banks need to understand the factors that influence the perception of an individual to add greater value to customers in terms of delivering financial products and services through innovative delivery channels. Most of marketing decision in terms of enhancing the effectiveness of delivery channels can be taken by considering these factors. There is also a need to educate the customers, so that effective, secure and safe use of innovative delivery channels can be made available to all and delivery channels can be used effectively for marketing of products and services too.

Practical implications/limitations: The identification of significant factors of customers' perception about delivery channels may be used more effectively by PSBs for cross-selling and up-selling of financial products and services. Our study was limited to the customers of PSBs of India, so the findings may be applicable to PSBs only and cannot be generalized.

Originality/value: This study was made on primary data, which has provided significant factors of customers' perception about technology being used by innovative delivery channels of PSBs of India. These significant factors can be helpful to PSBs for enhancing effectiveness of delivery channels.

Keywords: e-banking, innovative delivery channels, customer perception, technology adoption, PSBs of India

\section{Introduction}

The banking industry is definitely among the service industries that have been thoroughly transformed during the past decades. The direction of development has been toward more efficient mass services enabled by information and communication technologies (ICT). Technology adoption at various levels leads to enhanced customer service. It has become the core part of the functionality. Industries realized that to survive in market, they have to pace with innovation and creativity of products and services as well as the channels to deliver them. The competitive challenges forced upon the banking and financial institutions in particular the Public Sector Banks (PSBs) in India to change the delivery channels of their products or services. Today customers are just few clicks away from the fulfillment of their demands. The relationship marketing approach enables the financial institutions to develop a more productive, tailor-made and efficient interaction with its customers. At the same time, new technologies can be used for innovative promotion and thus, helps in maintaining personalized relationships.

Globally, there has been a rapid advancement in Information and Communication Technology (ICT), which has reflected in banks' business strategies, customer services and organizational structures, and among others too. Innovative adoption in the form of Internet banking, new generation ATMs and mobile applications have created 
a profound impact on the delivery channels of financial products and services. Also, a number of innovative developments in retail payments have emerged, which affect the retail payment market by influencing users in their choice of payment instruments and by significantly reshaping the payment processes.

Report on Trend and Progress of Banking in India 2012-13 by Reserve Bank of India (RBI) indicates that the growth of electronic payments has been impressive in recent years. However, the benefits of modern electronic payment systems are not spread evenly among all sections of society and across the different regions of the country. Despite multiple electronic modes of payment being available, cash is still the preferred and dominant mode of payment in large parts of the country. RBI in its Payment System Vision document 2012-15, aims to promote a less cash/less paper society, with increased emphasis on the use of electronic payment products and services, especially by the populace which is still not covered by these products.

\subsection{Automation in Public Sector Banks (PSBs) of India}

Generally banking in India is fairly mature in terms of supply, product range and reach although reach in rural India and to the poor still remains a challenge. The government has developed initiatives to address this through the PSBs expanding its branch network and through the National Bank for Agriculture and Rural Development (NABARD) and implemented the concept of microfinance.

The process of automation started in the early 1980s when RBI set up two committees in quick succession to accelerate the pace of automation of operations in the banking sector. A high-level committee was formed under the chairmanship of Dr. C. Rangarajan, then Deputy Governor of RBI, to draw up a phased plan for computerization and mechanization in the banking industry over a five-year time frame of 1985-1989. The financial reforms that were initiated in the early 1990s and the globalization and liberalization measures brought in a completely new operating environment to the banks. The bankers are now offering innovative and interactive technology-based services and products such as 'Anywhere Anytime Banking', 'ATM Banking', 'Tele-Banking', 'Internet Banking', 'Web Banking', ' Mobile Banking', etc., to their customers to cope with the competition.

\subsection{Delivery Channels Background}

Information Technology (IT) has helped in increasing the speed and efficiency of banking operations by facilitating the emergence of innovative products and new delivery channels. The role of the RBI as the driver of technology initiatives in the banking sector assumes greater importance given the challenges posed by rapid advancements in technology. The RBI has played important role in implementation of information technology.

Another change which is taking place slowly but at a steady pace is the use of alternatives to cash by most of the constituents of banks. The large scale use of cards for settlement of financial transactions whether credit cards or debit cards or even the new smart cards proves doubt that cash is slowly losing the prominence of the yester years. It is gratifying to note that banks are quickly adapting themselves to provide for non-cash based services too. This development has, however, to be looked at from an opportunity for banks to cash in on certain invisible benefits. It is a recognized fact that the cost of servicing a transaction conducted through an Automated Teller Machine or through an electronic mode such as the Internet is substantially less than a physical service to a customer from a counter of a branch. The proliferation of ATMs and the network of ATMs are the indicators of the initiatives of banks in this direction.

Winning in the new economy depends crucially on strategically effective and intelligent management of marketing and customer relationships. The first and foremost important shift required by banks is to treat the customer as a customer of the bank and not as a customer of any particular branch. Technology enables the customer "help themselves" through PC / Internet banking, ATM banking and telephonic banking. It also enables banks to fine tune their marketing strategies to the right targets for the right products at the right time. Indeed, the competitive edge that any bank requires to retain its existing customers is by providing such innovative services which offer them the convenience of transaction from anywhere, at any time by using delivery channels made suitable for them. Therefore, the imperative need would be to inculcate an attitudinal change in the mindset of bankers -towards providing services through such innovative, simple and secure means. However it may be borne in mind that technology dependent customer relationship management need not necessarily be 'cold' and 'mechanical' but must carry an individual dimension displaying personalized uniqueness, relevance and accuracy. The intangible factors of conduct such as likeableness, timeliness and creativity should be reflected as vital characteristics of corporate culture thus, enhancing customer satisfaction. 


\section{Literature Review}

\subsection{Role of Technology in Delivering Financial Services}

In recent past the financial sector in India has witnessed multifold increase in online activities. (Joseph et al., 1999) found that there is significant increase in use of technology by banks for delivery of their products and services as it reduces cost of transaction as well as ensures faster and confirm delivery of services.

(Timewell \& Young, 1999) found that the way of doing business by banks has changed. Now banks have started innovating their products and services suitable to their customers. (Ramsay \& Smith, 1999) have stated the banks have started realizing that they must understand their customer needs more closely and should innovate their products and services best suited to their customers, if they want to retain the existing customers and acquire new ones. (Mattila \& Hanin, 2000) have shown that there is shift from branch banking and traditional channels such as ATMs towards online banking. They suggested that banks are delivering real value to its customers through online delivery of their products and services. (Essinger, 1999; Kimball \& Gregor, 1995) have concluded that saving in transaction cost on the basis of implementation of virtual banking should not be at cost of customer's interest and competitive edge.

The use of financial services is characterized by individuality, mobility, independence of place and time, and flexibility (Karjaluoto et al., 2002; Jayawardhena \& Foley, 2000; Locarek-Junge \& Schwaiger, 1998; Roemer \& Buhl, 1996; Spiegel, 1996). In today's economy, the challenge is to provide the right information at the right time through suitable communication channel. (Mattila, 2001) has studied the interactive banking and suggested that marketing and advertising will get even more targeted and customized. The buyers' behavior pattern is valuable information. (Berger, 2003) has shown that by deployment of new technologies there are likely improvements in bank performance and consolidation of the banking industry in the US.

\subsection{Service Quality}

Service quality has been defined in services marketing literature as an overall quality assessment of service by the customers. Perceived service quality is believed to be resulting from comparison between customers' prior expectations about the service and their perceptions after actual experience of service performance (Asubonteng et al., 1996; Parasuraman et al., 1985). Service quality has been defined by the practitioners in terms of key dimensions that customers use while evaluating the services (Lewis \& Booms, 1983). Conceptualization of service quality should include both the service delivery process (Parasuraman et al., 1985) as well as the service outcomes (Lehtinen \& Lehtinen, 1991). (Gronroos, 1984) offered a service quality model with dimensions of technical quality (what consumer gets), functional quality (how consumer gets the service) and corporate image (how consumers perceive the firm and its services). Most of the studies have examined the service quality in banking related to internet banking, ATM and phone banking (Curran \& Meuter, 2005). Presently there is need to understand the factors affecting the customer satisfaction irrespective of technology being used by the banks.

\subsection{Technology Enabled Service Quality}

Automated search, communication among customers, information acquisition, content, mass customization, and ease of use have been identified as newer dimensions of service quality (Bailey \& Pearson, 1983; Doll \& Torkzadeh, 1988; Peterson et al., 1997). Meuter et al. (2000) studied the self service technology and categorized them on the basis of technology interface. Meuter et al. (2003) found that the willingness of the customers to use and adapt to newer technologies affect their perceptions of service quality, and the level of technology anxiety. Parasuraman (2000) used the technology readiness index to measure the service quality in technology-enabled services. Parasuraman et al. (2005) developed a scale on the basis of four dimensions viz., efficiency, fulfillment, system availability and privacy to assess the electronic service quality (E-S-QUAL). In the technology-based service, service recovery is one of the important factors affecting service quality perception of customers. Further, taking into account the responsiveness, compensation and contact. Parasuraman et al. (2005) also developed a scale for electronic service recovery quality (E-RecS-QUAL). Curran and Meuter (2005) found that the perception of the customer about service quality depends upon the type of self service technology (SST).

\subsection{Technology Adoption}

(Al-Hawari et al., 2005) established the critical determinants of automated service quality and they proposed a model for the banking sector of automated service quality based on the customers' perceptions (Yang et al., 2004) studied the reliable means of online service quality based on a broad conceptual framework which integrates theory and conceptualization in customer service quality, information systems quality, and product portfolio management, into online service quality. Joseph and Stone (2003) studied various roles played by technology and its impact on the delivery of banking services in the US banking sector. 
Chen et al. (2008) produced an integrated model to synthesize the essence of technology readiness index (TRI), technology acceptance model (TAM), and theory of planned behavior (TBP) to explain customers' continued use of self-service technology (SST). Elliott and Meng (2009) explored Chinese customers' attitude and behavior toward the use of new technology only with the help of TRI. However, they were not able to measure the likelihood of customers to use new technology. The earlier researches on technology adoption in Indian context have studied either cultural issues or impact of TAM (De Angeli et al., 2004), thus individualistic factors like Acceptability, safety, innovativeness, and security issues have not been considered, which also affect customers' decision to try out and adopt new technologies particularly SSTs.

\subsection{Customer Satisfaction}

In the area of marketing, comprehensive study has been made on customer satisfaction (Anderson et al., 2004; Fornell, 1992; Oliver, 1980). For practicing managers, customer satisfaction is prominent measurement metrics, because of its association with all types of products and services (Gupta \& Zeithaml, 2006). Oliver (1993) considered customer satisfaction a transaction-oriented element which was outcome of post purchase judgment or disconfirmation effect. Customer's overall experience with a product or service provider is considered as a cumulative satisfaction perspective and it also affects the future consumer behaviour (Johnson et al., 2001; Krepapa et al., 2003).

Service quality is found to be a strong predictor of customer satisfaction (Cronin \& Taylor, 1992; Cronin et al., 2000; Dabholkar et al., 2000; Spreng \& Mackoy, 1996). Levesque and McDougall (1996) find that in traditional retail banking the service problems and the bank's service recovery ability have a major impact on customer satisfaction and intentions to move to other bank. Several studies have been made in similar areas in which service quality dimensions of banking have been tested as predictors of customer satisfaction (Krepapa et al., 2003; McDougall \& Levesque, 2000; Ndubisi \& Wah, 2005). Al-Hawari and Ward (2006) found that customer satisfaction has an important role in understanding financial performance in a banking automated service context.

\subsection{Technology Adoption - a Tool for Effective and Efficient Customer Satisfaction}

(Eyadat and Kozak, 2005) have shown a positive correlation between the level of implemented technology and profitability/cost savings between 1992 and 2003 for the US banking sector. Malhotra and Singh (2009) revealed that perceived risk has a negative impact on behavioral intention of internet banking adoption and trust has a negative impact on perceived risk. A well-designed web site was also found to be helpful in facilitating easier use and also minimizing perceived risk concerns regarding internet banking usage.

Preceding research has suggested that the customer's perception about the service provide is based on the customer's service experience. (Brady et al., 2002) examined the ability of the performance-only measurement approach to capture the variance in consumers' overall perceptions of service quality. (Carrillat et al., 2009) found that service quality of the firm plays an important role in building long-term relationships with customers.

Musara and Fatoki, (2010) have revealed that technological advancement is commonly accompanied by real cost reduction in the production process. The two major advantages of technological adoption are: (a) reduction in banks' operational costs (the cost advantage); (b) facilitating more efficient transactions among customers within the same network (the network effect). Rajput and Gupta, (2011) studied the Indian banking sector for the period 2005-06 to 2009-10 and suggested efficiency gains resulting from technological innovations and investment in IT.

Not every consumers embrace SST in the retail environment. Some consumers actively seek out self scanning checkouts, online banking services, and internet shopping options. Other consumers, however, intentionally avoid such SSTs. For example, some retailers who are using in-store internet kiosks have found that not all consumers are interested in using the new technology (Mearian, 2001). However, bank service automation is becoming a critical factor in the process of trying to attain cost-effectiveness, which can be used as a strategic competitive weapon in the financial services market. Many financial institutions have clearly embarked on the development of technology-driven strategies, which they hope will be translated in terms of customer preferences and consequently, higher returns and market penetration (Goode et al., 1996).

\section{Methodology}

The structured questionnaire was developed in consultation with bank staff and academicians, and a pilot questionnaire was circulated to target audience (customers of PSBs) to evaluate its effectiveness. (Fishbein et al., 1975) study was taken into account while deciding the scales to measure the responses. The perceptions of the 
customers were measured with five-point Likert scales (Likert, 1932) and semantic differentials given by (Osgood et al., 1957). The brevity and clarity of the questions have been ensured.

The survey as well as in person interview of PSBs customers has been conducted. The main aim of the personal interview was to have a thorough understanding of customer's perception about Bank's technology for innovative delivery channels.

The random sampling method was adopted for selection of sample. To have a representative sample of the population, the equal representation of the age, gender and geographical location was ensured. Total 540 questionnaires were sent to individual bank customers in India. 107 responses were received in the beginning. After a follow-up further 197 responses were received. Total 304 responses were received from the 19 Public Sector Banks (PSBs) customers, out of which 250 were found suitable for data analysis. The response rate was 56.3 percent. The sample consisted of the customers' perception about technology used for delivery channels of the public sector banks in India.

Further, 19 in-depth interviews with banking customers and bank staff have been conducted. The interviews were conducted to have a thorough understanding into the survey responses, the existence of bank's technology for delivery channels and to verify the results.

\section{Data Analysis/Findings}

\subsection{Demographic Representation}

Table 1 show the demographics that the respondents of the sample are representative of the population in India on several variables.

Table 1. Respondent profile

\begin{tabular}{|c|c|c|}
\hline \multirow{2}{*}{$\begin{array}{l}\text { Demographic } \\
\text { Characteristics } \\
\text { Gender }\end{array}$} & \multicolumn{2}{|c|}{ No. of Respondents Percentage } \\
\hline & & \\
\hline Female & 54 & 21.6 \\
\hline Male & 196 & 78.4 \\
\hline Total & 250 & \\
\hline \multicolumn{3}{|l|}{ Age } \\
\hline $18-25$ years & 47 & 18.8 \\
\hline $26-35$ years & 97 & 38.8 \\
\hline $36-45$ years & 58 & 23.2 \\
\hline $46-59$ years & 34 & 13.6 \\
\hline Above 59 years & 14 & 5.6 \\
\hline Total & 250 & \\
\hline \multicolumn{3}{|l|}{ Annual Income } \\
\hline Not applicable & 2 & 0.8 \\
\hline$<2$ lakh & 43 & 17.2 \\
\hline$>2$ lakh to 5 lakh & 114 & 45.6 \\
\hline$>5$ lakh to 10 lakh & 63 & 25.2 \\
\hline$>10$ lakh & 28 & 11.2 \\
\hline Total & 250 & \\
\hline \multicolumn{3}{|l|}{ Location } \\
\hline Urban & 96 & 38.4 \\
\hline Metro & 154 & 61.6 \\
\hline Total & 250 & \\
\hline \multicolumn{3}{|l|}{ Qualification } \\
\hline Undergraduate & 25 & 10 \\
\hline Graduate & 71 & 28.4 \\
\hline Post-graduate & 64 & 25.6 \\
\hline Doctoral & 3 & 1.2 \\
\hline Professional & 82 & 32.8 \\
\hline Others & 5 & 2.0 \\
\hline Total & 250 & \\
\hline
\end{tabular}




\begin{tabular}{lcl}
\hline Occupation & & \\
Student & 6 & 2.4 \\
Homemaker & 15 & 6 \\
Self-employed & Business 68 & 27.2 \\
Salaried & 145 & 58 \\
Others & 16 & 6.4 \\
Total & $\mathbf{2 5 0}$ & \\
\hline
\end{tabular}

\subsection{Exploratory Factor Analysis}

Factor analysis used to understand the range of factors that have a strong influence on the customer perception for delivery channels.

It was observed that Kaiser-Meyer-Olkin Measure of Sampling Adequacy KMO value was 0.802, which was more than the recommended value of 0.6 for sample adequacy. Bartlett's test of sphericity was also significant as value was $0.000(\mathrm{p}<0.001)$.

The initial Eigen values of 5 factors are greater than 1 and the factor loading is more than 0.5 . Hence, Table 2 explained how 16 factors have been reduced to 5 factors. The total cumulative percentage of the extracted factors is more than $50 \%$ i.e. $61.88 \%$, which is a fairly good for the sample size of 250 . Under Rotated Component Matrix, the components having $>0.50$ initial Eigen value have been taken together with the principal components respectively.

Table 2. Total variance explained

\begin{tabular}{|c|c|c|c|c|c|c|c|c|c|}
\hline \multirow{2}{*}{ Component } & \multicolumn{3}{|c|}{ Initial Eigenvalues } & \multicolumn{3}{|c|}{$\begin{array}{l}\text { Extraction Sums of Squared } \\
\text { Loadings }\end{array}$} & \multicolumn{3}{|c|}{ Rotation Sums of Squared Loadings } \\
\hline & Total & $\begin{array}{l}\% \text { of } \\
\text { Variance }\end{array}$ & Cumulative $\%$ & Total & $\begin{array}{l}\% \text { of } \\
\text { Variance }\end{array}$ & Cumulative $\%$ & Total & $\%$ of Variance & Cumulative \% \\
\hline 1 & 4.984 & 31.152 & 31.152 & 4.984 & 31.152 & 31.152 & 2.127 & 13.294 & 13.294 \\
\hline 2 & 1.528 & 9.551 & 40.704 & 1.528 & 9.551 & 40.704 & 2.116 & 13.223 & 26.517 \\
\hline 3 & 1.230 & 7.690 & 48.394 & 1.230 & 7.690 & 48.394 & 2.081 & 13.009 & 39.526 \\
\hline 4 & 1.138 & 7.115 & 55.509 & 1.138 & 7.115 & 55.509 & 2.061 & 12.880 & 52.406 \\
\hline 5 & 1.020 & 6.374 & 61.883 & 1.020 & 6.374 & 61.883 & 1.516 & 9.477 & 61.883 \\
\hline 6 & .951 & 5.946 & 67.829 & & & & & & \\
\hline 7 & .805 & 5.032 & 72.860 & & & & & & \\
\hline 8 & .765 & 4.780 & 77.640 & & & & & & \\
\hline 9 & .752 & 4.698 & 82.338 & & & & & & \\
\hline 10 & .617 & 3.858 & 86.196 & & & & & & \\
\hline 11 & .489 & 3.056 & 89.253 & & & & & & \\
\hline 12 & .429 & 2.683 & 91.936 & & & & & & \\
\hline 13 & .392 & 2.451 & 94.387 & & & & & & \\
\hline 14 & .362 & 2.262 & 96.649 & & & & & & \\
\hline 15 & .281 & 1.758 & 98.407 & & & & & & \\
\hline 16 & .255 & 1.593 & 100.000 & & & & & & \\
\hline
\end{tabular}

Note. Extraction Method: Principal Component Analysis. 
Table 3. Factor reliability

\begin{tabular}{|c|c|c|c|c|}
\hline Factor & $\begin{array}{l}\text { Scale } \quad(\% \quad \text { variance } \\
\text { explained })\end{array}$ & $\begin{array}{l}\text { Factor } \\
\text { Loading }\end{array}$ & Reliability & Variables included in the factor \\
\hline \multirow{4}{*}{ F1 } & \multirow{4}{*}{ Acceptability (13.3\%) } & 0.505 & \multirow{4}{*}{0.671} & Bank's technology is personalized \\
\hline & & 0.736 & & Bank's technology recognizes customers' by name \\
\hline & & 0.738 & & Bank's technology provides the precise information that needed \\
\hline & & 0.524 & & Bank's technology provides the needed reports / statements \\
\hline \multirow{3}{*}{ F2 } & \multirow{3}{*}{ Safety $(13.2 \%)$} & 0.774 & \multirow{3}{*}{0.718} & Bank's technology is safe to use \\
\hline & & 0.762 & & The risk associated with the bank's technology is low \\
\hline & & 0.692 & & $\begin{array}{l}\text { Personal information exchanged while using technology is not } \\
\text { misused by the bank }\end{array}$ \\
\hline \multirow{3}{*}{$\mathbf{F 3}$} & \multirow{3}{*}{ Availability (13 \%) } & 0.803 & & $\begin{array}{l}\text { Bank's technology provides on-line support through Frequently } \\
\text { Asked Questions (FAQs). }\end{array}$ \\
\hline & & 0.850 & 0.761 & Bank's help desk provides $24 \times 7$ supports with updated information. \\
\hline & & 0.662 & & $\begin{array}{l}\text { Bank delivery channels are customized / developed to complete } \\
\text { queries / transactions quickly }\end{array}$ \\
\hline \multirow{3}{*}{ F4 } & \multirow{3}{*}{$\begin{array}{l}\text { User } \\
(\mathbf{1 2 . 8 \% )}\end{array}$} & 0.787 & \multirow{3}{*}{0.689} & Bank's technology is user friendly \\
\hline & & 0.802 & & Bank's technology is reliable \\
\hline & & 0.593 & & Bank's technology never fails \\
\hline \multirow{3}{*}{ F5 } & \multirow{3}{*}{ Accessibility (9.5\%) } & 0.503 & \multirow{3}{*}{0.292} & Bank's technology is accessible beyond regular business hours \\
\hline & & 0.619 & & $\begin{array}{l}\text { Bank's technology gives more freedom of mobility i.e. using the } \\
\text { banking services while on move }\end{array}$ \\
\hline & & 0.646 & & $\begin{array}{l}\text { It is more convenient to use delivery channels than interacting with } \\
\text { Bank's employees }\end{array}$ \\
\hline
\end{tabular}

Latest and customized technology has been perceived by the customers as most preferred factor with $67 \%$ reliability, followed by safety and security with $72 \%$ reliability. Availability, user friendliness has been perceived by the customers as $3^{\text {rd }}$ and forth preferred factor with reliability of $76 \%$ and $69 \%$ respectively. The accessibility has been perceived as the $5^{\text {th }}$ preferred factor with $29 \%$ reliability which is far lower than the standard requirement of $50 \%$ as shown in Table III. Hence, $5^{\text {th }}$ factor can be further tested by taking higher sample size. Due to the advent of technology and delivery of financial products and services through Internet, the accessibility factor has been perceived by the respondents together with Internet or with the availability factor. Internet as a channel per say has wider accessibility. Similarly user friendliness might have been perceived by the respondents together with customized technology. With the above analysis it can be derived that the latest and customized technology, safety and security, availability and user friendliness have been perceived as preferred parameters.

The public sector banks may consider these parameters, while innovative any financial products and services to be delivered through innovative delivery channels. There will be higher probability of acceptance and use of such products and services over the delivery channels.

\subsection{Inferences Statistics}

A cross-tab analysis was done using SPSS 16.0 to understand the relationship and association of demographic variables with the reduced factors. Following was drawn through above analysis: 
Table 4. Relationship and association of demographic variables

\begin{tabular}{|c|c|c|c|c|c|c|c|c|c|c|c|c|}
\hline \multirow[t]{5}{*}{ Demographic Characteristics } & \multirow{5}{*}{$\begin{array}{l}\text { Total No. of } \\
\text { Respondents }\end{array}$} & \multirow{5}{*}{ Percentage } & \multicolumn{2}{|c|}{$\begin{array}{l}\text { Factor 1 } \\
\text { Acceptability }\end{array}$} & \multicolumn{2}{|l|}{$\begin{array}{c}\text { Factor } 2 \\
\text { Safety }\end{array}$} & \multicolumn{2}{|c|}{$\begin{array}{l}\text { Factor } 3 \\
\text { Availability }\end{array}$} & \multicolumn{2}{|c|}{$\begin{array}{l}\text { Factor } 4 \\
\text { User friendliness }\end{array}$} & \multicolumn{2}{|c|}{$\begin{array}{l}\text { Factor } 5 \\
\text { Accessibility }\end{array}$} \\
\hline & & & No. of & Percentage & No. of & Percentage & No. of & Percentage & No. of & Percentage & No. of & Percentage \\
\hline & & & Respondents & & Respondents & & Respondents & & Respondents & & Respondents & \\
\hline & & & Agrees to & & Agrees to & & Agrees to & & Agrees to & & Agrees to & \\
\hline & & & Factor 1 & & Factor 2 & & Factor 3 & & Factor 4 & & Factor 5 & \\
\hline \multicolumn{13}{|l|}{ Gender } \\
\hline Female & 54 & 21.6 & 29 & 11.7 & 24 & 9.6 & 21 & 8.3 & 21 & 8.4 & 37 & 14.8 \\
\hline Male & 196 & 78.4 & 111 & 44.3 & 108 & 43.3 & 85 & 33.9 & 102 & 40.9 & 134 & 53.5 \\
\hline \multicolumn{13}{|l|}{ Age } \\
\hline $18-25$ years & 47 & 18.8 & 25 & 10.1 & 25 & 10.1 & 15 & 6.0 & 27 & 10.9 & 33 & 13.3 \\
\hline $26-35$ years & 97 & 38.8 & 60 & 23.8 & 56 & 22.4 & 26 & 10.3 & 52 & 20.8 & 72 & 28.9 \\
\hline $36-45$ years & 58 & 23.2 & 24 & 9.6 & 25 & 10.1 & 13 & 5.2 & 22 & 8.9 & 35 & 14.0 \\
\hline $46-59$ years & 34 & 13.6 & 20 & 7.8 & 18 & 7.3 & 10 & 4.1 & 14 & 5.7 & 22 & 8.8 \\
\hline Above 59 years & 14 & 5.6 & 9 & 3.7 & 7 & 2.9 & 4 & 1.7 & 7 & 2.9 & 8 & 3.2 \\
\hline \multicolumn{13}{|l|}{ Annual income } \\
\hline Not applicable & 2 & 0.8 & 2 & 0.8 & 1 & 0.5 & 1 & 0.5 & 2 & 0.7 & 1 & 0.5 \\
\hline$<2$ lakh & 43 & 17.2 & 23 & 9.3 & 23 & 9.2 & 20 & 7.9 & 22 & 8.9 & 20 & 8.0 \\
\hline$>2$ lakh to 5 lakh & 114 & 45.6 & 69 & 27.6 & 64 & 25.7 & 53 & 21.2 & 60 & 24.0 & 60 & 23.9 \\
\hline$>5$ lakh to 10 lakh & 63 & 25.2 & 31 & 12.4 & 31 & 12.4 & 22 & 8.8 & 30 & 12.0 & 34 & 13.6 \\
\hline$>10$ lakh & 28 & 11.2 & 12 & 4.9 & 13 & 5.1 & 9 & 3.7 & 10 & 3.9 & 15 & 5.9 \\
\hline \multicolumn{13}{|l|}{ Location } \\
\hline Urban & 96 & 38.4 & 57 & 22.7 & 53 & 21.3 & 41 & 16.4 & 49 & 19.7 & 69 & 27.7 \\
\hline Metro & 154 & 61.6 & 81 & 32.3 & 79 & 31.6 & 64 & 25.7 & 74 & 29.6 & 101 & 40.5 \\
\hline \multicolumn{13}{|l|}{ Qualification } \\
\hline Undergraduate & 25 & 10 & 11 & 4.2 & 12 & 4.9 & 8 & 3.1 & 11 & 4.4 & 7 & 2.7 \\
\hline Graduate & 71 & 28.4 & 45 & 18.0 & 36 & 14.5 & 34 & 13.7 & 35 & 14.0 & 37 & 14.9 \\
\hline Post-graduate & 64 & 25.6 & 37 & 14.8 & 38 & 15.3 & 31 & 12.5 & 31 & 12.4 & 36 & 14.4 \\
\hline Doctoral & 3 & 1.2 & 1 & 0.5 & 2 & 0.7 & 2 & 0.7 & 1 & 0.4 & 2 & 0.7 \\
\hline Professional & 82 & 32.8 & 41 & 16.2 & 40 & 16.1 & 28 & 11.3 & 43 & 17.3 & 46 & 18.3 \\
\hline Others & 5 & 2.0 & 3 & 1.3 & 3 & 1.3 & 2 & 0.8 & 2 & 0.8 & 2 & 0.9 \\
\hline \multicolumn{13}{|l|}{ Occupation } \\
\hline Student & 6 & 2.4 & 4 & 1.6 & 5 & 1.9 & 2 & 0.9 & 4 & 1.5 & 3 & 1.1 \\
\hline Homemaker & 15 & 6 & 7 & 2.8 & 6 & 2.4 & 4 & 1.5 & 6 & 2.5 & 7 & 2.8 \\
\hline Self-employed / Business & 68 & 27.2 & 36 & 14.5 & 37 & 14.9 & 26 & 10.3 & 38 & 15.1 & 40 & 15.9 \\
\hline Salaried & 145 & 58 & 82 & 32.6 & 76 & 30.5 & 67 & 26.8 & 69 & 27.5 & 73 & 29.2 \\
\hline Others & 16 & 6.4 & 9 & 3.5 & 8 & 3.2 & 7 & 2.7 & 7 & 2.8 & 6 & 2.5 \\
\hline
\end{tabular}

It is evident from Table 4 that most of the demographic characteristics have shown their preference of agreement in accessibility, i.e. factor 5, however reliability of this factor is lowest (Table 3). There may be gap in technology implementation by Public Sector Banks (PSBs) and the interfaces or support services provided by third parties; such as Internet, payment gateway etc. Inadequate arrangement of attending customer's grievances beyond business hours and on mobility may be one of the reasons of lower reliability of this factor even after higher preference of agreement. It may be further investigated for larger sample and with additional associated dimensions. Customers of over 59 years and lower and middle-income range have shown their preference of agreement to acceptability of technology. The customers belonging to homemaker and salaried under occupation segment have also shown similar preference.

\section{Conclusion}

Channels must continuously strive to add greater value to customers in terms of delivering services through innovative channels. Public Sector Banks (PSBs) also need to understand the factors that influenced the perception of an individual. The study shows the factors such as Technology acceptability, safety, availability, user friendliness and accessibility highly depends on the demographic profile of the population size. Most of marketing decision in terms of enhancing the effectiveness of delivery channels can be taken by considering 
these factors. Also customers are exposed to newer technology, which helps them to generate information by fewer clicks, should be channelized by Public Sector Banks (PSBs) by providing value added services. The application of crosstabs helps to understand variables, which are influencing the decision in relation to marketing of financial products and services through delivery channels.

\section{Managerial Implication}

An attempt has been made to understand the customers' perception about the technology adoption by Public Sector Banks (PSBs) on five factors viz., acceptability, safety, availability, user friendliness, and accessibility, so that the gap between adoption and acceptance of technology for innovative delivery channels may be identified and bridged. The identification of significant factors of customers' perception about technology used by delivery channels may give significant direction to Public Sector Banks (PSBs) for more effective cross-selling and up-selling of financial products and services. This study was made on the primary data, which has provided significant factors of customers' perception about technology being used for innovative delivery channels by PSBs of India. These significant factors may be helpful to PSBs for enhancing effectiveness of delivery channels too. Similar studies may be made for other banking sectors. This approach may also be helpful in studying the business processes like e-tailing, micro payments, mobile payments etc.

\section{Limitations and Future Research Directions}

Our study was limited to the customers of Public Sector Banks (PSBs) of India, so the findings may be more closely applicable to PSBs only. The findings of this study may be used to test the possibility of multi-tier service quality model for delivery of technology enabled banking products and services.

\section{References}

Al-Hawari, M., \& Ward, T. (2006). The effect of automated service quality on Australian banks' financial performance and the mediating role of customer satisfaction. Marketing Intelligence \& Planning, 24(2), 127-147. http://dx.doi/10.1108/02634500610653991

Al-Hawari, M., Hartley, N., \& Ward, T. (2005). Measuring banks' automated service quality: a confirmatory factor analysis approach. Marketing Bulletin, 16, 1-19.

Anderson, E. W., Fornell, C., \& Mazvancheryl, S. K. (2004). Customer satisfaction and shareholder value. Journal of Marketing, 68(4), 172-185. http://dx.doi.org/10.1509/jmkg.68.4.172.42723

Asubonteng, P., McCleary, K. J., \& Swan, J. E. (1996). SERVQUAL revisited: a critical review of service quality. The Journal of Services Marketing, 10(6), 62-81. http://dx.doi.org/10.1108/08876049610148602

Bailey, J. E., \& Pearson, S. W. (1983). Development of a tool for measuring and analyzing computer user satisfaction. Management Science, 29(5), 530-545. http://dx.doi.org/10.1287/mnsc.29.5.530

Berger, A. N. (2003). The Economic Effects of Technological Progress: Evidence from the Banking Industry. Journal of Money, Credit and Banking, 35(2), 141-176. http://dx.doi.org/10.2139/ssrn.332900

Brady, M. K., Cronin, J. J., \& Brand, R. R. (2002). Performance-only measurement of service quality: a replication and extension. Journal of Business Research, 55, 17-31. http://dx.doi.org/10.1016/S0148-2963(00)00171-5

Carrillat, F. A., Jaramillo, F., \& Mulki, J. P. (2009). Examining the impact of service quality: a meta-analysis of empirical evidence. Journal of Marketing Theory and Practice, 17(2), 95-110. http://dx.doi.org/10.2753/MTP1069-6679170201

Chen, S. C., Chen, H. H., \& Chen, M. F. (2008). Determinants of satisfaction and continuance intention towards self-service technologies. Industrial Management and Data Systems, 109(9), 1248-1263. http://dx.doi.org/10.1108/02635570911002306

Committee on Mechanisation in the Banking Industry. (1984). Retrieved from http://rbidocs.rbi.org.in/rdocs/Publications/PDFs/4459.pdf

Cronin, J. J. Jr., \& Taylor, S. A. (1992). Measuring service quality: a reexamination and extension. Journal of Marketing, 56(3), 55-68. http://dx.doi.org/10.2307/1252296

Cronin, J. J. Jr., Brady, M. K., \& Hult, G. T. M. (2000). Assessing the effects of quality, value, and customer satisfaction on consumer behavioral intentions in service environments. Journal of Retailing, 76(2), 193218. http://dx.doi.org/10.1016/S0022-4359(00)00028-2 
Curran, J. M., \& Meuter, M. L. (2005). Self-service technology adoption: comparing three technologies. Journal of Services Marketing, 19(2), 103-113. http://dx.doi.org/10.1108/08876040510591411

Dabholkar, P., Shepherd, C. D., \& Thorpe, D. I. (2000). A comprehensive framework for service quality: an investigation of critical conceptual and measurement issues through a longitudinal study. Journal of Retailing, 76(2), 139-173. http://dx.doi.org/10.1016/S0022-4359(00)00029-4

De Angeli, A., Athavankar, U. A., Joshi, A., Coventry, L., \& Johnson, G. I. (2004). Introducing ATMs in India: a contextual enquiry. Interacting with Computers: Global Human-Computer Systems, 6(1), 29-44. http://dx.doi.org/10.1016/j.intcom.2003.11.003

Doll, W. J., \& Torkzadeh, G. (1988). The measurement of end-user computing satisfaction. MIS Quarterly, 12(2), 259-274.

Dorsch, M. J., Swanson, S. R., \& Kelley, S. W. (1998). The role of relationship quality in the stratification of vendors as perceived by customers. Journal of Academy of Marketing Science, 26(2), 128-142. http://dx.doi.org/10.1177/0092070398262004

Elliott, K. M., \& Meng, J. (2009). Assessing Chinese consumers' likelihood to adopt self-service technologies. International Business and Economics Research Journal, 8(2), 27-40.

Essinger, J. (1999). The virtual banking revolution. The customer, the bank and the future. London: International Thomson Business Press.

Eyadat, M., \& Kozak, S. (2005). The Role of Information Technology in the Profit and Cost Efficiency Improvements of the Banking Sector. Journal of Academy of Business and Economics, 5(2), 70-75.

Fishbein, M., \& Ajzen, I. (1975). Belief, attitude, intention, and behaviour: An introduction to theory and research. Massachusetts: Addison-Wesley.

Fornell, C. (1992). A national customer satisfaction barometer: the Swedish experience. Journal of Marketing, 56(1), 6-21. http://psycnet.apa.org/doi/10.2307/1252129

Goode, M. M. H., Moutinho, L. A., \& Chien, C. (1996). Structural equation modeling of overall satisfaction and full use of services for ATMs. International Journal of Bank Marketing, 14(7), 4-11. http://dx.doi.org/10.1108/02652329610151331

Gronroos, C. (1984). A service quality model and its marketing implications. European Journal of Marketing, 18(4), 36-44. http://dx.doi.org/10.1108/EUM0000000004784

Gupta, S., \& Zeithaml, V. (2006). Customer metrics and their impact on financial performance. Marketing Science, 25(6), 718-739. http://dx.doi.org/10.1287/mksc.1060.0221

Internet Usage Statistics. (2013). Retrieved from http://www.internetworldstats.com/stats.htm

Jayawardhena, C., \& Foley, P. (2000). Changes in the banking sector-the case of Internet banking in the UK. Internet Research: Electronic Networking Applications and Policy, 10(1), 19-30. http://dx.doi.org/10.1108/10662240010312048

Johnson, M. D., Gustafsson, A., Andreassen, T. W., Lervik, L., \& Cha, J. (2001). The evolution and future of national customer satisfaction index models. Journal of Economic Psychology, 22(2), 217-245. http://dx.doi.org/10.1016/S0167-4870(01)00030-7

Joseph, M., \& Stone, G. (2003). An empirical evaluation of US bank customer perceptions of the impact of technology on service delivery in the banking sector. International Journal of Retail \& Distribution Management, 31(4), 190-202. http://dx.doi.org/10.1108/09590550310469185

Joseph, M., McClure, C., \& Joseph, B. (1999). Service quality in the banking sector: the impact of technology on service delivery. International Journal of Bank Marketing, 17(4), 82-191. http://dx.doi.org/10.1108/02652329910278879

Karjaluoto, H., Mattila, M., \& Pento, T. (2002). Electronic banking in Finland-consumer beliefs and reactions to a new delivery channel. Journal of Financial Services Marketing, 6(4), 346-361. http://dx.doi.org/10.1057/palgrave.fsm.4770064

Kimball, R., \& Gregor, W. (1995). How distribution is transforming retail banking: Changes leading banks are making. Journal of Retail Banking Services, 17(3), 1-9. 
Krepapa, A., Berthon, P., Webb, D., \& Pitt, L. (2003). Mind the gap: an analysis of service provider versus customer perceptions of market orientation and the impact on satisfaction. European Journal of Marketing, 37(1/2), 197-218. http://dx.doi.org/10.1108/03090560310454253

Lehtinen, U., \& Lehtinen, J. R. (1991). Two approaches to service quality dimensions. The Service Industries Journal, 11(3), 287-303. http://dx.doi.org/10.1080/02642069100000047

Levesque, T., \& McDougall, G. H. G. (1996). Determinants of customer satisfaction in retail banking. International Journal of Bank Marketing, 14(7), 12-20. http://dx.doi.org/10.1108/02652329610151340

Lewis, R. C., \& Booms, B. H. (1983). The marketing aspects of service quality. In Berry, L. L., Shostack, G. L. and Upah, G. D. (Eds.), Emerging Perspectives on Services Marketing (pp. 99-104). Chicago, IL: American Marketing Association.

Likert, R. (1932). A technique for the measurement of attitudes. Archives of Psychology, 21(14), 5-54.

Locarek-Junge, H., \& Schwaiger, M. (1998). Realizing customer retention potentials by electronic banking. Electronic Markets, 8(4), 23-26. http://dx.doi.org/10.1080/10196789800000051

Malhotra, P., \& Singh, B. (2009). Determinants of Internet banking adoption by banks in India. Internet Research, 17(3), 323-339. http://dx.doi.org/10.1108/10662240710758957

Mattila, M. (2001). Essays on Consumers in the Dawn of Interactive banking. Dissertation, ER-PainoKy, Lievestuore.

Mattila, M., \& Hanin, A. (2000). The real value of electronic banking. Developments in Marketing Science, 23, 398-402. http://dx.doi.org/10.1007/978-3-319-11885-7

McDougall, G. H. G., \& Levesque, T. (2000). Customer satisfaction with services: putting perceived value into the equation. Journal of Services Marketing, 14(5), 392-410. http://dx.doi.org/10.1108/08876040010340937

Mearian, L. (2001). Staples installing internet kiosks in all US retail stores. Computerworld, 30, 1-3.

Meuter, M. L., Ostrom, A. L., Bitner, M. J., \& Roundtree, R. (2003). The influence of technology anxiety on consumer use and experiences with self-service technologies. Journal of Business Research, 56(11), 899906. http://dx.doi.org/10.1016/S0148-2963(01)00276-4

Meuter, M. L., Ostrom, A. L., Roundtree, R. I., \& Bitner, M. J. (2000). Self-service technologies: understanding customer satisfaction with technology-based service encounters. Journal of Marketing, 64(3), 50-64. http://dx.doi.org/10.1509/jmkg.64.3.50.18024

Musara, M., \& Fatoki, M. (2010). Has Technological Innovations resulted in Increased Efficiency and Cost Savings for Banks' Customers? African Journal of Business Management, 4(9), 1813-1821.

Ndubisi, N. O., \& Wah, C. K. (2005). Factorial and discriminant analyses of the underpinnings of relationship marketing and customer satisfaction. International Journal of Bank Marketing, 23(7), 542-557. http://dx.doi.org/10.1108/02652320510629908

Oliver, R. L. (1980). A cognitive model of the antecedents and consequences of satisfaction decisions. Journal of Marketing Research, 17(4), 460-469. http://dx.doi.org/10.2307/3150500

Oliver, R. L. (1993). Cognitive, affective and attribute bases of the satisfaction response. Journal of Consumer Research, 20(3), 418-430.

Operation and Performance of Commercial Banks. (2013). Retrieved from http://www.rbi.org.in/scripts/PublicationsView.aspx?id=15440

Osgood, C., Suci, G., \& Tannenbaum, P. (1957). The measurement of meaning. Urbana: University of Illinois Press.

Parasuraman, A. (2000). Technology readiness index (TRI): a multiple-item scale to measure readiness to embrace new technologies. Journal of Service Research, 2(4), 307-320. http://dx.doi.org/10.1177/109467050024001

Parasuraman, A., Zeithaml, V. A., \& Berry, L. L. (1985). A conceptual model of service quality and its implications for future research. Journal of Marketing, 49(4), 41-50. http://dx.doi.org/10.2307/1251430 
Parasuraman, A., Zeithaml, V. A., \& Malhotra, A. (2005). E-S-QUAL: a multiple-item scale for assessing electronic service quality. Journal of Service Research, 7(3), 213-233. http://dx.doi.org/10.1177/1094670504271156

$\begin{array}{llllll}\text { Payment system vision document-vision 2012-15. (2012). Retrieved from } & \end{array}$ Http://rbidocs.rbi.org.in/rdocs/publicationreport/pdfs/vdbp270612.pdf

Peterson, R. A., Balasubramanian, S., \& Bronnenberg, B. J. (1997). Exploring the implications of the Internet for consumer marketing. Journal of the Academy of Marketing Science, 25(4), 329-346. http://dx.doi.org/10.1177/0092070397254005

Rajput, N., \& Gupta, M. (2011). Impact of IT on Indian Commercial Banking Industry: DEA Analysis. Global Journal of Enterprise Information System, 3(1), 17-31. http://dx.doi.org/10.15595/gjeis/2011/v3i1/33546

Ramsay, J., \& Smith, M. (1999). Managing customer channel usage in the Australian banking sector. Managerial Auditing Journal, 14(7), 329-338. http://dx.doi.org/10.1108/02686909910289812

Report on Trend and Progress of Banking in India 2012-13. (2013). Retrieved from http://rbidocs.rbi.org.in/rdocs/Publications/PDFs/0RTP21112013_F.pdf

Roemer, M., \& Buhl, H. (1996). Das Web als alternative zur bankfiliale: gestaltung innovativer IKS für das direktbanking. Wirtschaftsinformatik, 6, 565-577.

Spiegel, V. (1996). Marketing as an exchange of value. In C. Field (Ed.), New strategies for managing information technology. London: Chapman \& Hall.

Spreng, R. A., \& Mackoy, R. D. (1996). An empirical examination of a model of perceived service quality and satisfaction. Journal of Retailing, 72(2), 201-214. http://dx.doi.org/10.1016/S0022-4359(96)90014-7

Talwar, R. K. (1977). Customer Service in Banks. Mumbai: IBA Publication.

Timewell, S., \& Young, K. (1999). How the Internet redefines banking. The Banker, 6, $27-30$.

Yang, Z., Joon, M., \& Peterson, R. T. (2004). Measuring customer perceived online service quality: scale development and managerial implications. International Journal of Operations \& Production Management, 24(11), 1149-1174. http://dx.doi.org/10.1108/01443570410563278

\section{Copyrights}

Copyright for this article is retained by the author(s), with first publication rights granted to the journal.

This is an open-access article distributed under the terms and conditions of the Creative Commons Attribution license (http://creativecommons.org/licenses/by/3.0/). 